\title{
Instructional Materials: A platform to enhance cognitive skills and writing development
}

\section{Los materiales educativos: fundamentos para promover el desarrollo de la escritura y de las habilidades mentales}

\author{
Jorge Enrique Muñoz Oyola \\ Part time Professor \\ Universidad EAN (Escuela de Administración de Negocios) \\ English Instructor Uniempresarial \\ E-mail: jem0345@gmail.com
}

\begin{abstract}
This paper describes the results of an action research project carried out with first graders at a private coeducational school in Bogotá, Colombia. The purpose of the study was to account for children's cognitive skills and writing development when using designed instructional materials based on the Structural Cognitive Modifiability model (SCM). The findings of the research suggest that children's cognitive skills development evolves through a three-stage ongoing cycle. The findings also reveal that they become creative writers by recalling prior knowledge and integrating L1 and L2 elements. This study shows that mediation serves as a bridge between learners' difficulties and understanding, highlights the use of L1 as a language acquisition facilitator.
\end{abstract}

Key words: Cognitive skills, writing process, Structural Cognitive Modifiability, mediation.

\section{Resumen}

Este artículo describe los resultados de un proyecto de investigación-acción realizado con niños de primer grado en un colegio mixto privado en Bogotá, Colombia. El objetivo de este estudio fue examinar el desarrollo de la escritura y de las habilidades cognitivas de los niños al usar materiales diseñados con base en el modelo de la Modificabilidad Estructural Cognitiva (MEC). Los resultados de la investigación proponen que el desarrollo de las habilidades mentales de los niños evoluciona a través de un ciclo de tres etapas y que a su vez los niños se convierten en escritores creativos al usar el conocimiento previo y al integrar elementos de la lengua materna y de la lengua extranjera. Este estudio demuestra que la mediación sirve como puente entre las dificultades de los estudiantes y la comprensión, y resalta el uso de la lengua materna como facilitador en la adquisición de una lengua.

Palabras claves: Habilidades mentales, proceso de escritura, Modificabilidad Estructural Cognitiva, mediación.

* Received 03-11-2009 / Accepted 17-01-2010 


\section{Introduction}

Contemporary research into the nature of English language teaching emphasizes the role of classroom materials as an essential element to give students the opportunity to develop strategies for understanding (Richards, 2001). A large part of this research has been based on the idea that materials need to be learner-centered, use realistic language, and provide learners with opportunities to use the target language to achieve communicative purposes (Tomlinson 1998). Considering that materials may be able to effectively teach English to students, the concern is how we can use them to go beyond English language teaching and foster students' cognition and independent writing while learning a foreign language.

This action research project deals with the design of instructional materials at a coeducational school in Bogotá, Colombia. The English textbooks children used were not intellectually stimulating, but simply grammar-focused, limiting students' creativeness, and leading them to copy models. In order to address this concern, instructional materials were created based on the Structural Cognitive Modifiability theory (SCM), a theory which purports that intelligence is not static but dynamic and able to be modified by means of mediated learning experiences. The materials were implemented in the classroom not only to teach language (English) but, also to scrutinize first graders' writing development and determine if such materials did or did not influence the progress of cognitive skills such as identification, comparison, classification, differentiation, decoding, synthesis, analysis and the use of divergent thinking.

The project makes evident that children go through a learning process determined by stages when they are encouraged to use materials that are cognitively-challenging. The data analysis also supports the idea that the L2 writing development is fully nourished by the use of prior knowledge and the native language that becomes cognitive scaffolding rather than an obstacle in the language acquisition process.

The ideas portrayed in this paper not only give teachers a new perspective to adapt or develop materials that better fit students' interests and needs, but also challenges the status quo in the Colombian education system, which is often defined by the dependence on commercial learning materials. In spite of the fact that textbooks are a great support for educators, this research invites teachers to exploit their potential as material developers as all teachers have the capacity to develop more contextualized materials due to their expertise, knowledge, creativity and resourcefulness.

\section{Theoretical framework}

As the materials proposed in this study took into account learners' cognition and writing development with the purpose of fostering effective learning in the EFL classroom, this project is based on three foremost constructs: cognitive skills, materials development and children's writing.

\section{Cognitive skills within The Structural Cognitive Modifiability (SCM) model}

The Structural Cognitive Modifiability Model (SCM) is a theoretical construct pioneered by Feuerstein (as cited in Pilonieta, 2004) whose main premise is that intelligence is not a static or fixed trait. On the contrary, it is characterized by dynamism and its capacity to be modified.

The model works under the assumption that if learners are guided in an appropriate manner, they will develop their capacity to transfer the principles they learned to new situations. To put these ideas in his words, Feuerstein (as cited in 
Pilonieta, 2004) states that "human development is only possible if people are empowered to act in a coherent and intelligent way according to their necessities (...) What is important is to create the real conditions 'to do well' what one has been able 'to think well'"' (p. 9).

Feuerstein (cited in Martínez, Brunet, $\varepsilon$ Farrés, 1991) defines cognitive skills or mental operations as "the whole internalized, organized and coordinated actions by which information proceeding from external and internal sources is processed" (p. 40). In this regard, these mental operations are vital for the individual to develop formal mental processes since they lead the organism to interact, act or respond to different sources of information. Feuerstein (as cited in Pilonieta, 2003) states that there are eighteen mental operations that a human being uses when processing information, however, in this project, I only selected eight mental operations since children at the age of seven are mainly intuitive rather than analytical (Piaget, 1983, 1985). The following table describes the cognitive skills selected.

Table 1. Cognitive Skills

\begin{tabular}{|l|l|}
\hline 1. Identification & The ability to recognize one specific reality (phenomenological or virtual) by means of its features \\
\hline 2. Differentiation & $\begin{array}{l}\text { Complete acknowledgment of the properties of things, phenomena, situations and relations by } \\
\text { specifying what is relevant from what is irrelevant }\end{array}$ \\
\hline 3. Comparison & $\begin{array}{l}\text { The act of comparing implies establishing similarities and differences of the referent or criterion in } \\
\text { very diverse levels }\end{array}$ \\
\hline 4. Classification & $\begin{array}{l}\text { The capability to organize data into inclusive and higher categories. It is to understand the different } \\
\text { types and levels of order of things once the criteria have been previously established }\end{array}$ \\
\hline 5. Decoding & $\begin{array}{l}\text { The capability that lets the individual translate not only instructions but also codes, formulae, languages } \\
\text { and so on including the non-verbal language }\end{array}$ \\
\hline 6. Analysis & $\begin{array}{l}\text { The process that implies separating the elements or parts from a whole by taking into account a specific } \\
\text { criterion such as relationship, function, use, structure, property, and so forth }\end{array}$ \\
\hline 7. Synthesis & $\begin{array}{l}\text { It complements analysis. Specifically, synthesis is the process that permits to integrate elements, } \\
\text { relationships, properties, parts, etc, in order to form new and meaningful entities or totalities }\end{array}$ \\
\hline $\begin{array}{l}\text { 8. Divergent } \\
\text { thinking }\end{array}$ & $\begin{array}{l}\text { To construct new types of relationships, spaces and dynamics based on the ones that have been built } \\
\text { up in the mind as virtual reality }\end{array}$ \\
\hline
\end{tabular}

1 I have translated most of the definitions concerning the SCM theory from Spanish into English. This information has been taken from Pilonieta's seminar given at Gimnasio Los Andes School in Bogotá in 2006.
Additionally, Feuerstein (cited in lafrancesco, 2005) affirms that human beings can process information and learn efficiently if the subject has the necessary cognitive functions with which to develop his or her cognitive skills. The 
author defines cognitive functions as "the basic prerequisites of intelligence which let, from the cognitive processes, internalize information and self-regulate the organism to facilitate meaningful learning" (p. 29). Feuerstein (cited in Iafrancesco, 2002) fully explains that they are classified into the three levels of the mental act: Input Cognitive Functions, Elaboration Cognitive Functions and Output Cognitive Functions. The following table shows the cognitive functions taken from the SCM model which were crucial to carrying out this action research:

Table 2. Cognitive Function

\begin{tabular}{|c|c|}
\hline \multicolumn{2}{|c|}{$\begin{array}{l}\text { Input Cognitive Functions } \\
\text { They refer to quantity and the quality of data that an individual stores before finding the solution to a problem }\end{array}$} \\
\hline 1. Clear perception & The accurate and precise knowledge of information in a simple and familiar way \\
\hline $\begin{array}{l}\text { 2. Systematic exploration of a } \\
\text { learning situation }\end{array}$ & $\begin{array}{l}\text { The capability to organize and plan the stored information in a } \\
\text { systematic way }\end{array}$ \\
\hline $\begin{array}{l}\text { 3. Linguistic abilities at the input } \\
\text { level }\end{array}$ & $\begin{array}{l}\text { The ability to discriminate and differentiate objects, events, relationships and operations } \\
\text { by means of verbal rules by establishing meanings of symbols and signs }\end{array}$ \\
\hline 4. Organization of information & The capability to simultaneously use different sources of information \\
\hline \multicolumn{2}{|c|}{$\begin{array}{l}\text { Elaboration Cognitive Functions } \\
\text { They refer to the organization and structuralization of information in the solution to a problem }\end{array}$} \\
\hline $\begin{array}{l}\text { 1. Perception and definition of a } \\
\text { problem }\end{array}$ & $\begin{array}{l}\text { The ability to delimit what the problem asks for, in other words, which aspects are to be } \\
\text { selected and how to find them out }\end{array}$ \\
\hline 2. Selection of relevant information & $\begin{array}{l}\text { The capability to choose the previously stored and relevant information to solve the } \\
\text { problem }\end{array}$ \\
\hline 3. Amplitude and flexibility & $\begin{array}{l}\text { The ability to use different sources of information by establishing an appropriate } \\
\text { coordination and combination among them }\end{array}$ \\
\hline 4. Comparative behavior & $\begin{array}{l}\text { The capability to make all kinds of comparisons and relate objects and events by } \\
\text { anticipating a situation }\end{array}$ \\
\hline 5. Behavior planning & $\begin{array}{l}\text { The ability to develop the necessary steps to find the solution to a problem in a } \\
\text { sequential and accumulative way }\end{array}$ \\
\hline 6. Cognitive Classification & The capability to organize data into inclusive and higher categories \\
\hline \multicolumn{2}{|c|}{$\begin{array}{l}\text { Elaboration Cognitive Functions } \\
\text { They refer to the accurate and precise communication of the answer or solution to the problem stated }\end{array}$} \\
\hline $\begin{array}{l}\text { 1. Elaboration when communicating } \\
\text { the answer }\end{array}$ & The capability to express the answer in a fast, correct and systematic way \\
\hline 2. Accuracy in the answers & $\begin{array}{l}\text { The ability to think and express the correct answer to a problem or a general learning } \\
\text { situation }\end{array}$ \\
\hline 3. Visual transport & The capability to complete figures and transport them visually \\
\hline 4. Answers control & The ability to reflect before giving any kind of answer \\
\hline
\end{tabular}


Feuerstein's model was the pillar of this project since it provided the foundations to understand the human being's cognitive processes. Besides arguing that an individual's mental operations are irremovable, the author claims that such operations may be modified as long as learners have mediated learning experiences. Considering mediation as "the quality of interaction that is established among people and between them and the situations" (Feuerstein, as cited in Pilonieta, 2004, p.9), the author states that it is only possible to foster learning if teachers create the conditions to maximize students' thinking and provide them with guidance. Thus, learners are able to modify their own cognitive structure since mediated learning experiences lead students to identify deficiencies and use strategies to correct them.

\section{Materials Design}

Tomlinson (1998) defines materials development as "anything which is done by writers or teachers to provide sources of language input and to exploit these sources in ways which maximize the likelihood of intake: in other words the supplying of information about and/or experience of the language in ways designed to promote language learning" (p.2).

Similarly, the author outlines that materials are "anything which is used to help to facilitate the learning of a language. Materials can be in the form of a textbook, a workbook, a cassette, a CD-Rom, a video, a photocopied handout, a newspaper, a paragraph written on a whiteboard: anything which presents or informs about the language being learned" (p.xi).

Besides providing these essential definitions, Tomlinson (1998) also poses some basic principles relevant to the development of materials that teachers should take into consideration when designing resources with the purpose of promoting language learning. As the author gives many principles to develop materials, the following table just portrays the foundations taken for this project in order to make the materials design achievable.

Table 3. Materials Development Principles

\begin{tabular}{|l|l|}
\hline 1. Materials should achieve impact & $\begin{array}{l}\text { Impact is achieved by means of novelty (unusual topics, } \\
\text { illustrations and activities), variety (breaking up the monotony } \\
\text { with an unexpected activity), attractive presentation (use of eye- } \\
\text { catching colors and photographs) and appealing content (topicsof } \\
\text { interest which offer the possibility to learn something new) }\end{array}$ \\
\hline $\begin{array}{l}\text { 2. Materials should help learners to } \\
\text { feel at ease }\end{array}$ & $\begin{array}{l}\text { Materials should have a supportive and relaxed voice and relate } \\
\text { the world of the book to the world of the learner. This is possible } \\
\text { if teachers chat to learners and consider their preferences, } \\
\text { interests and opinions }\end{array}$ \\
\hline $\begin{array}{l}\text { 3. Materials should expose the } \\
\text { learners to language in authentic }\end{array}$ & $\begin{array}{l}\text { Materials should provide frequent exposure to comprehensible } \\
\text { and authentic input which is rich and varied. They should also } \\
\text { stimulate learner interaction with the input rather than receive just } \\
\text { passive reception of it }\end{array}$ \\
$\begin{array}{l}\text { 4. Materials should provide the } \\
\text { learners with opportunities } \\
\text { to use the target language to } \\
\text { achieve communicative purposes }\end{array}$ & $\begin{array}{l}\text { Interaction can be achieved through information and opinion gap } \\
\text { activities (when learners communicate with each other), and } \\
\text { creative writing and speaking activities (including stories and } \\
\text { dramas) }\end{array}$ \\
\hline
\end{tabular}




\begin{tabular}{|l|l|}
\hline 5. Materials should maximize & In order to facilitate deeper learning, materials should include \\
learning potential by encouraging & convergent thinking activities such as writing and doing logical and \\
intellectual, aesthetic and & sequential tasks in order to activate the left half of the brain. In \\
emotional involvement which & addition, materials should also include divergent thinking \\
stimulates both right and left & activities such as visual and imaginative tasks (shapes, sizes) that \\
brain activities & may stimulate the right half of the brain.
\end{tabular}

McDonough and Shaw (2000) provide us with insights about their perspective on materials, stating that resources "cannot be seen in isolation, but are embedded within a broader professional context" (p.5). The authors purport that materials are involved in a macro level, including the learners on the one hand and the educational setting on the other. In relation to the former, the researchers state that teachers should consider students' age, interests, level of proficiency in English, aptitudes, preferred learning styles and personality. Regarding the latter, they assert that educators need to consider the whole teaching and learning environment including the role of English in the school, the number of pupils, the time available, physical environment (building, noise factors, tables, chairs, etc) and the sociocultural environment (appropriate topics to the setting).

In addition to this, Cunningsworth (1984) mentions that "course materials for English should be seen as the teacher's servant and not his master" (p. 65), leaving room to reflect on terms such as inspiration and creativity. The author states that materials should give possibilities for further development, serving as an inspiration to educators who at the same time have to move away from dependence on resources.

Nuñez et al. (2009) build on Cunningsworth's ideas when pointing out that experts and native speakers are not the only ones who may develop materials for language teaching. The authors affirm that this belief needs to be demystified because pre-service, novice and in-service teachers can also contribute to the language-learning process by embarking the fascinating task of creating materials. Furthermore, the researchers state that the principles relevant to the development of materials may be grouped into three categories: content, form and personal traits.

The first component embraces comprehensible input, attention to linguistics features, interlanguage, communicative activities, language level difficulty, brain stimulation, beliefs, pronunciation, and writing tasks. In regard to the second element, form, the authors synthesize the following issues: attractive layout and novelty including challenging and motivating tasks. In relation to the last category, personal traits, the authors encourage educators to consider foremost elements when developing materials: self-confidence, discovery, curiosity, expectation, learners' interest and needs, learning styles, previous knowledge, personal experiences, cultural background and motivational feedback.

Nuñez et al (2009) purport that pre-service and in-service teachers may develop own materials if they engage in reflection about the teaching principles that inform such materials. As a matter of that, the authors state that "careful examination of such principles will provide with sufficient criteria to determine whether the materials will satisfy the purpose for which they were developed. Assessing materials involves the process of evaluating, piloting and making adjustments" (p. 46).

\section{Children's writing development fostered by materials}

Pérez (1998) states that the natural process of written language acquisition is described as a 
Piagetian assimilation schema process. In other words, children carry out tasks by transforming and adding new information to their cognitive structure. The author explains that children use their prior knowledge and experience with the purpose of constructing or conveying meaning in written productions. This idea relies on the schema theory explained by Anderson and Pearson (cited by Cooper, 1993a) who point out that "as new knowledge and information are gained, the mind creates new file folders or schemata to an existing schema" (p.110).

Ferreiro (1994) asserts that learners need to develop certain cognitive skills in order to deal with written marks. As children do not invent new symbols but interpret the relationship between written strings and oral language, they need to identify language elements including their properties and relations. From a cognitive stance and building on the SCM model, this means that children need to develop certain basic operations to engage in the literacy process: identification, comparison, differentiation, decoding and analysis.

In order to develop children's writing by means of materials, the process-approach orientation was more suitable during the implementation of the materials since it focuses on the individual and relies on children's capability to create, discover, think and reformulate writing (Kern, 2000). Moreover, children's writing in this project relied on what Cooper (1993b) calls independent writing in which students write by themselves assuming they are able to fulfill the tasks with little or no support from other sources. Stating that children wrote independently during the development of the tasks does not mean that they did not receive support when putting ideas on the paper. On the contrary, they were provided with the guidance and vocabulary needed to express their ideas. Independent writing in this investigation implied that children were not given models to transcribe. Conversely, learners had the opportunity to compare, decode, classify, analyze, synthesize and use their divergent thinking by themselves when turning their ideas into written texts ${ }^{2}$. The activities were modeled and explained to ensure that they knew the how, but not the what.

\section{Methodology}

This qualitative research was descriptive as well as interpretative because it presents a detailed account of the development of both cognitive skills and writing when children used materials based on the Structural Cognitive Modifiability model. The action research carried out in a first grade classroom focused on the following two questions: What happens to first graders' cognitive skills when using materials based on the Structural Cognitive Modifiability model? How do children develop as EFL writers when using these types of materials?

Burns (1999) states that action research is a systematic procedure including eleven stages by which daily issues are researched in the classroom. Such stages are: exploring, identifying, planning, collecting data, analyzing/ reflecting, hypothesizing/ speculating, intervening, observing, reporting, writing and presenting. These stages are depicted as follows:

Phase 1 (Exploring). The problem was identified: the children's textbooks were not intellectually stimulating but grammar-focused, which limited students' creativeness.

Phase 2 (Identifying). The focus was refined: to enhance cognition and writing development by means of materials design.

Phase 3 (Planning). A needs assessment was conducted to let the children's voices be heard before implementing the materials (see Appendix 6).

2 See the materials designed (Appendixes 1-5). 
Phase 4 (Collecting data). Two workshops were designed to explore the children's cognition and writing (see Appendix 7).

Phase 5 (Analyzing/reflecting). Once the two workshops were implemented, children reflected at home by means of learning logs to evaluate these materials in terms of content, participation and process (See Appendix 8). After having analyzed the children's responses, I found out the following aspects:

\section{Process}

The children enjoyed the hands-on activities. However, some students found the tasks difficult because they did not have all the necessary vocabulary and because they were not provided with enough examples.

\section{Participation}

The children interacted with two main purposes: to ask for clarification, and to talk about the difficulty of the materials, the way they decorated the workshop and their life experiences.

\section{Content}

The children mentioned that they had a great time when cutting and gluing jigsaw puzzles because they were challenging and innovative tasks. However, some students were unwilling to write because they were unmotivated and lacked enough vocabulary to express their ideas in the target language.

Phase 6 (Hypothesizing/speculating). Once the findings previously mentioned were obtained, some conclusions, which served as a basis for the planning of the instructional design, were stated. Such reflections are depicted as follows.

1. Throughout this exploratory stage, it was evident that my role as a teacher and as a mediator was crucial in order to have students carry out the tasks successfully.
2. The materials were meaningful to them because they triggered their prior knowledge and made them retrieve life experiences to share with others.

3. It was observed that the children needed to be very familiar with the foreign language and carry out more pre-writing activities to both their ideas and avoid frustration.

Phase 7 (Intervening). Once the findings and the conclusions of this exploratory stage were drawn, the materials were designed in order to enhance children's cognition and writing development.

Phase 8 (Observing). After having conducted the intervention which consisted of nine sessions, the data were analyzed by using the grounded approach. The findings of the study will be fully described in the data analysis section.

\section{Setting}

This research took place at a coeducational private school located in the northern part of Bogotá, Colombia. The school is monolingual and it offers children an intensified English program, which was developed throughout eight hours of communication and two hours of workshop, for a total of 10 English hours per week. The English Department followed a task-based syllabus and the children worked with a textbook, a workbook and a short story book to achieve the goal of the "Plan de Estudios": to make students use English by identifying, describing, and interpreting the environment and its features in written and spoken manners.

\section{Participants}

\section{The Students}

This action research project was conducted with twenty-seven 6-7 year old children from one of the two first grade classes with which I worked. When selecting the learners, I took 
into consideration a course in which students attended classes frequently and parents were willing to participate in the project. I sent parents a consent form in order to obtain their permission to have children write their logs at home during the exploratory stage, and worked with the same participants during the whole year.

\section{The Researcher}

As the teacher researcher in all the stages of the study, I was the materials designer, the participant, the observer and the mediator. I asked the principal for permission at the school to conduct my project; I talked to parents to explain them what and why I would be carrying out the project. I asked parents to help their children write reflections at home and finally, I designed nine workshops to be implemented once a week for the intervention stage, which aimed at enhancing children's cognitive skills and independent writing.

\section{Data Collection Instruments}

Four main instruments were employed in this project with the purpose of collecting data: students' artifacts, videotapes, field notes and conferences. The conferences were mainly used to fully interpret the children' writing tasks. These instruments are described as follows.

\section{Students' Artifacts}

I consider this source of data important for my research because it is tangible of what kids are able to do and of the range of responses kids make to different learning tasks. Such samples were an important platform of acknowledgment about students' cognition and language learning because they contained "untainted" reliable information that arose from their literacy process. These pieces of work were collected once a week by putting them into folders.

\section{Videotapes}

Hubbard and Power (1999) assert that videotapes give teachers insights into untapped aspects of their classrooms". (p.98). In other words, this instrument allowed me to analyze the dynamics of the class regarding participation, interaction and children's behavior when working with the materials. This instrument, which was used on the same day students received the materials, allowed observation of whether or not students understood the tasks, needed help with the vocabulary and structures, used sources of information, made comparisons, used strategies to solve a problem and if they were able to complete figures and transport them visually.

\section{Field Notes}

Arhar et al. (2001) affirm that field notes are "direct observations of what is being said and done as well as impressions or hunches of the observer" (p.140). Accordingly, this data collection instrument was essential for this project since I was able to capture what actually happened in the classroom while children were working with the materials created. The field notes I wrote during the observations were taken in the midst and after the fact; in other words, I first wrote key words in a small notebook during the implementation, and then sought a quiet place for reflection to reconstruct what had happened in the classroom.

\section{Conferences}

In this study, the conferences were addressed not only to inquire into writing, but also to deepen my understanding about children's drawings since they accounted for their prior knowledge ${ }^{3}$. Conferences were held after class in order to ask students about their drawings and writings.

3 The students' prior knowledge evident in divergent thinking tasks is elucidated in the data analysis section. 


\section{Process for Data Collection}

First of all, the 27 students were given a folder to keep track of their work and to have easier access to it. The workshops were implemented once a week and gathered in the corresponding folders at the end of the class to make sure that all the information was complete. While children were working on the materials, an external person videotaped the class with the purpose of capturing the children's behavior and participation. After the implementation, the field notes were transcribed. As it was mentioned above, conferences were used to give a solid foundation to the interpretation of children's work.

\section{Findings}

Triangulation, which is defined by Freeman (1998) as multiple sources of information or points of view on the phenomenon or question investigated, was used with the purpose of validating the data analysis. Accordingly, field notes, videotapes, students' artifacts and conferences were used for the triangulation and the two categories below answer the questions stated in this research.

Table 4. Research questions and categories

\begin{tabular}{|l|l|}
\hline \multicolumn{1}{|c|}{ QUESTION } & \multicolumn{1}{c|}{ CATEGORY } \\
\hline $\begin{array}{l}\text { What happens to first } \\
\text { graders' cognitive skills } \\
\text { when using materials based } \\
\text { on the Structural Cognitive } \\
\text { Modifiability? }\end{array}$ & $\begin{array}{l}\text { 1. Children move from difficulties to the } \\
\text { use of cognitive strategies through a } \\
\text { mediated process determined by stages }\end{array}$ \\
\hline $\begin{array}{l}\text { How do children develop as } \\
\text { EFL writers when using these } \\
\text { types of materials? }\end{array}$ & $\begin{array}{l}\text { 2. From words to paragraphs: An } \\
\text { ongoing process in which children use } \\
\text { their background and integrate language } \\
\text { elements to develop their own writing } \\
\text { style }\end{array}$ \\
\hline
\end{tabular}

The first category answers my first research question since it accounts for children's cognitive functions and scrutinizes how children developed their cognitive skills throughout the implementation of materials based on the Structural Cognitive Modifiability model. The second category answers the second question of this research since it describes the language elements that children used and the writing process through which children developed their own writing style.

Children move from difficulties to the use of cognitive strategies through a mediated process determined by stages

Children had many difficulties when solving the tasks proposed in the first stage of the process since they gave answers impulsively and did not know what to do in order to carry out the workshops. I called this first stage Uncertainty and Emerging Strategies. In the second stage, it was evident that the children started using their own strategies to solve the tasks despite having difficulties in working with the workshops. I named this second stage Difficulties Remain but the Strategies Increase. In the last stage, which is called Strengthening of Cognitive Strategies, children strengthened their cognitive functions in order to do the tasks proposed. The three stages the children went through are fully explained below.

\section{First Stage: Uncertainty and emerging stra- tegies}

This stage took place while implementing the first 3 workshops. The children seemed lost since the instructions in the foreign language were not clear to them and the materials sometimes created confusion due to the pictures selected ${ }^{4}$. This fact led children to ask for frequent help to really understand the purpose of the activity.

4 Workshop 2 (Appendix 1) illustrates that the instructions and the example were confusing. Workshop 2 (Annex 2) shows that the fence could be likely used for both the horse and the cow. Observation and reflection helped me overcome these difficulties during the implementation. 
Moreover, the children showed impulsive behavior as they did not take time to think and give an accurate response, but answered without organizing their ideas. The following excerpt shows that the children found it hard to take some time to think before giving an answer as they had not developed the ability to plan and systematize the knowledge received.

The boy ACC writes the word "foot" instead of "feet" which is the correct answer. When I see this, I approach him and ask if the letters he wrote (o-o) coincide with the number displayed on the workshop. He looks at the bank and says "ahhh" when he notices that the number is 5 and that " $e$ " is the corresponding letter to write the word "feet" (see figure below).

(Field notes 1 , July $21^{\text {st }} 2006$ )

In spite of the fact that the children had difficulties during this first stage, a few of them used a cognitive strategy in the output phase that I called process reflection. These students reflected upon the process they followed to accomplish the activity and discovered the way in which the task could be carried out. The following example shows how a student reflects upon the things she should do in order to identify, differentiate and decode words:

LC: ¿Así teacher? Ya lo terminé (I approach and tell her to correct a mistake). ¡Ya sé!, me tengo que guiar por los números y escribir así las palabras

SS: ya lo sabía

(I go around the class and help her decode a word by pointing at the letters bank)

LC: ahh, yo me tengo es que fijar en todo (making reference to the fact that she must use all the information provided in the letters bank) (Video tape 1, July 21 ${ }^{\text {st }}$ 2006)

Considering that only a few children displayed the process reflection, it is important to remark that during this first stage they started becoming aware of the fact that they could think of what to do before solving a problem.

\section{Second Stage: The difficulties remain, but the strategies increase}

This stage describes the events that took place within the fourth and sixth workshops designed to enhance first graders' cognitive skills. I observed that the obstacles that appeared in the first stage were also evident in this second phase. In addition, some children found it hard to visually transport images and to gather relevant information. In regards to the former, some children could not complete the pictures or transport them in a visual way when putting together the jigsaw puzzle (see Appendix 2, workshop 3). In relation to the latter, I observed that children did not use the necessary information to answer the task, but partly made use of relevant data (see Appendix 4 , workshop 6). The following excerpt illustrates the difficulty that children faced to gather relevant information during the second stage.

(VO says "teacher hay three!!" making reference to the number of Buzz Lightyears, however she did not count well because the answer is wrong; actually, there are four Buzzes in the workshop. SIF tells me "en todas es dos" so I say that all the answers are not two. I explain to him in Spanish that he has to read and then count. When I see that a kid is doing the exercise wrong, I point at the mistake and say "no, this is not the answer" for them to count again. Some kids like LA, AML, AC and LC write the wrong number. When I approach LC and explain to her again using the $L 1$, she says "ahh! Es que hay que contarlos todos!!" which means that she was only counting some of the drawings and she was not taking into consideration the total number of pictures. SS writes the answer to Woody wrong, so I tell him to count and correct. There are few children like NR who ask me "¿así está bien?” for me to verify the answers)

(Field Notes 6, October 13 ${ }^{\text {th }}, 2006$ ) 
This sample shows that students did not take into consideration all the images to answer the questions related to parts of the body, but just kept in mind a few pictures to do the task. This second stage was not only characterized by the continuity of problems, but also by the increase in the cognitive strategies the children made use of to deal with the materials. In other words, children not only continued employing the strategies from the first stage, but they also employed behavior planning, problem discernment and classification ability.

In relation to behavior planning, I observed that strategic students followed an order to finish the tasks and used their fingers on the page to count, cover images and follow labyrinth paths. Moreover, they cut and pasted the pictures required to work with the materials in an organized manner. The students who had a stratagem to work were more successful than the ones who had not internalized the capacity to plan a sequence of steps.

In addition, children started to discern the problem to deal with, that is to say, they identified what to do in the decoding process since they showed that they had a clear perception of the problem and knew how to use the sources of information. I also, observed in this second stage that children were able to analyze images and classify data according to specific criteria.

In regards to analysis, children could logically organize the sequence of a story since they had the ability to perceive the events analytically and integrate them with a coherent order. Concerning the classification skill, I observed that the children were able to discriminate words and put them into the correct category by using concepts they already knew from reality, such as objects, parts of the body and toys.

\section{Third Stage: Cognitive strategies strengthening}

The final stage illustrates what happened in the classroom within the seventh and the ninth workshops, aimed at enhancing first graders' cognitive skills. This third stage revealed that when the students were given the materials, they knew in advance that they needed to complete images, write sentences in the bubbles or draw pictures in the corresponding squares. The familiarization with the workshops and the ability to clearly understand the instructions facilitated the completion of the tasks and thus, the development of students' cognitive functions.

Additionally, children used their own strategies in order to plan the necessary steps to accomplish the task. First graders were not as impulsive as they were at the beginning of the implementation; on the contrary, most of them had the ability to systematize their behavior and become more strategic when carrying out the activities in the workshops. The following pictures show that strategic students, who used their fingers before tracing the path, were more successful than non-strategic students.

Moreover, in this final stage the children not only used the strategies evident in the two previous stages, but were also able to visually transport and sequence images, organize items into categories, look for differences, enhance their imagination when inventing pictures and sentences and complete words by using the letter bank (see Appendix 5).

However, the children found it very difficult to synthesize information given the fact that they did not understand the instructions in the foreign language nor did they have the complete ability to use relevant information. Therefore, perceiving the problem, organizing pertinent data and having enough linguistic resources are essential tools in the input phase that assure good thinking and high quality answers.

Teacher and peers' mediation bridges children and cognitive skills evolution

It is crucial to point out that the students' cognitive processes were enhanced by both 
their own strategies and the external mediation carried out by the teacher and the peers. The data analysis showed that mediation helped children develop their cognitive skills given that the teacher monitored, guided and used code-switching while learners used their L1 (Spanish) to help each other. The three stages revealed in the children's learning process showed that communication served as a bridge between students and their cognitive skills evolution and that interaction was a key factor in their learning process.

From words to paragraphs: An ongoing process in which children use their background and integrate language elements to develop their own writing style

This category answers the second question posed in this research, which is related to the way children developed as EFL writers when using materials based on the Structural Cognitive Modifiability model. Taking into consideration that writing is a "schema process" in which children restructure their knowledge and use experiences to convey meaning (Ferreiro as cited in Pérez, 1998), this category describes not only linguistic elements in children's writing, but also their life experiences and knowledge which served as a basis for the development of divergent thinking tasks and independent writing. To be specific, I focused the analysis of the data on both prior knowledge used by students and written productions in order to account for the children's cognitive scaffolding and language use.

Prior Knowledge: The scaffolding to accomplish divergent thinking tasks and independent writing

Children's conferences showed that the cognitive scaffolding used to invent pictures (divergent thinking tasks) or complete stories included three main issues: home, friendship and school. In regards to home, children showed that there were four aspects that influenced their written and drawn pieces of work: family, pets, toys and mass media. It is important to highlight that despite using prior knowledge related to the first three items, most children (22 out of 24) used what they had watched on TV programs, channels or movies (mass media) as a basis for completing tasks. The following passage shows the influence of mass media in children's writing and synthesis of images.

Furthermore, children showed the importance of friendship when doing divergent-thinking tasks since they related close friends to happiness and used their experiences with school mates to express their ideas by means of pictures or written messages. What makes this prior knowledge interesting in this study is the fact that all the learning gained from these experiences was socially constructed in the school setting. The influence of school experiences in children's writing is portrayed in the following example. 
Jorge Enrique Muñoz Oyola

Figure1. Students' Conversation about snakes

T: AT, ¿este que animal es?

S: Una serpiente

$\mathrm{T}: \quad$ ¿Una serpiente? ¿Y que tiene en la cola?

S: La cola

T: No pero ¿por qué tiene esas cositas así? (líneas en la cola)

S: Porque es una cascabel

T: ¿Una cascabel? ¿Y en donde has visto las serpientes cascabel?

S: No sé no las he visto

$\mathrm{T}$ : ¿No las has visto nunca nunca nunca?

S: No, sólo que Cesar, una vez encontró una piel de culebra $n$ el solario

T: ¡Uy! si ¿y cómo era?

S: Manchas blancas y negras

T: ¿Y que hicieron con la piel?

S: La botamos

$\mathrm{T}$ : Ahh!! ¿y que tiene aquí esas cositas rojas?

S: Bueno las manchas, deberían ser negras

T: Pero las hiciste rojas, o sea que nunca has visto una serpiente sólo la piel de Cesar

S: Si

T: ¿Y te dio miedo?

S: No

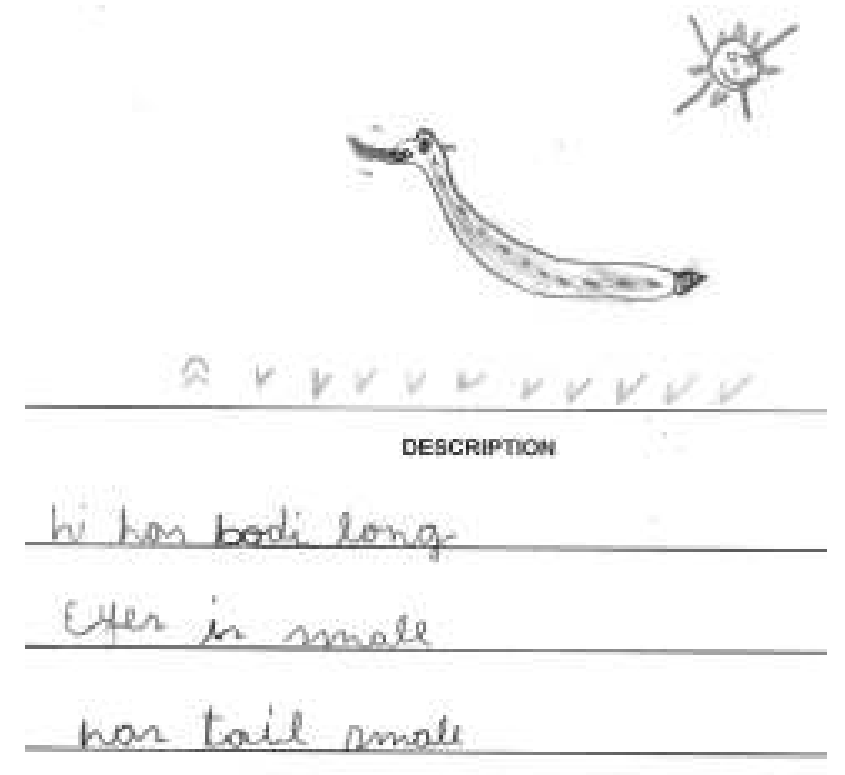

Language elements integration and writing style development

Throughout the implementation of the workshops, children made evident two main issues: the integration of L2 language elements and the use of Spanish as a resource to develop themselves as creative writers in the foreign language. Accordingly, children narrated some events in which they used the structure of a story (beginning, plot and ending), connectors (but, and, with), time adverbs (when), linking words (after), capital letters and adjectives to describe pictures and make their texts more coherent. The following samples show some of these elements in children's productions.
Figure 2. Language elements integration

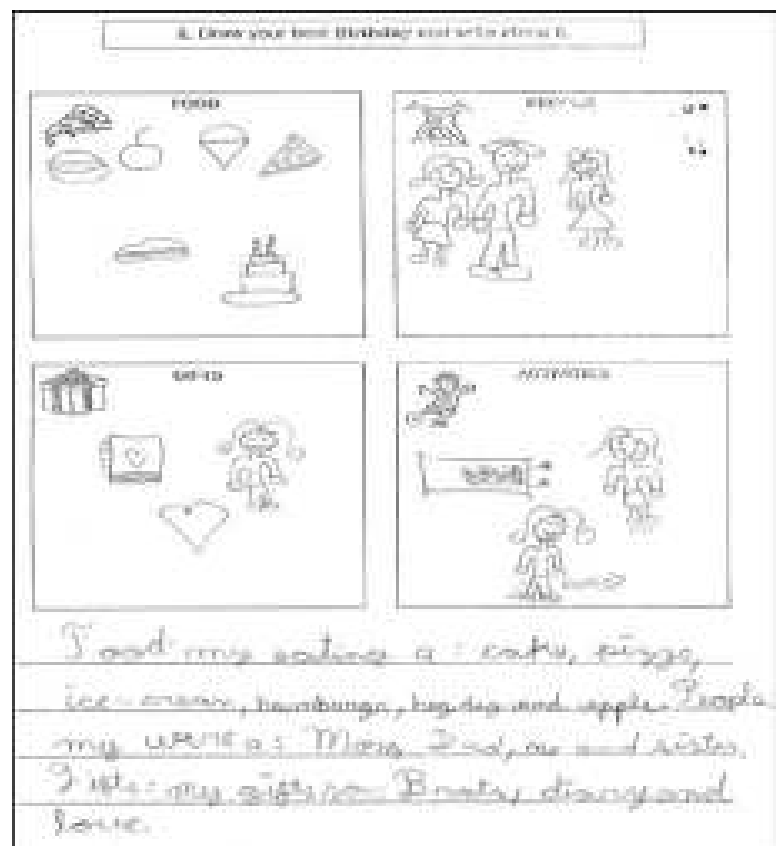


Besides utilizing such elements, children wrote ideas by means of different types of sentences that included narrative dialogues, and both interrogative and exclamatory expressions. Sometimes, the children created dialogues among the pictures displayed in the workshops and empowered the illustrations to think, ask and hold conversations on the paper. Children not only expressed an idea, but also created an intertextual communication in which the reader and the characters interacted by means of written words. The use of dialogues and exclamatory sentences are illustrated in the following sample:

Children's productions also showed that they developed their inner grammar about the L2 in their language acquisition process. The analysis revealed that the children first internalized language features such as pronouns (he, I, she), verbs (has, am, have) and articles (the, a) during the writing process and then overused these familiar words to develop their own hypothesis about the L2 grammar when writing independently. This crucial phase is what Selinker (cited by Ellis, 1997) calls interlanguage: "the interim grammars which learners build on their way to full target language competence" (p.30). The integration and overuse of these L2 elements are portrayed in the following sample.

Moreover, the analysis of the children's artifacts revealed that the use of their native language (Spanish) served as a basis for children to create written productions. Children not only developed as writers by integrating and overusing English features; they also used invented spelling, code-switching, L1 syntax and literal translations to carry out written tasks. It is important to highlight that Mejía (1998) supports the use of code-switching in the classroom by claiming that it "helps maximize learning opportunities in the bilingual classroom (p.9)". The author also states that teachers should consider "natural codewitching as a valuable tool for making meaning in the classroom, specially in the early stages of second or foreign language learning" (p.9). The following sample shows how children used Spanish as a resource to develop their writing.

Figure 3. Interlanguage construction
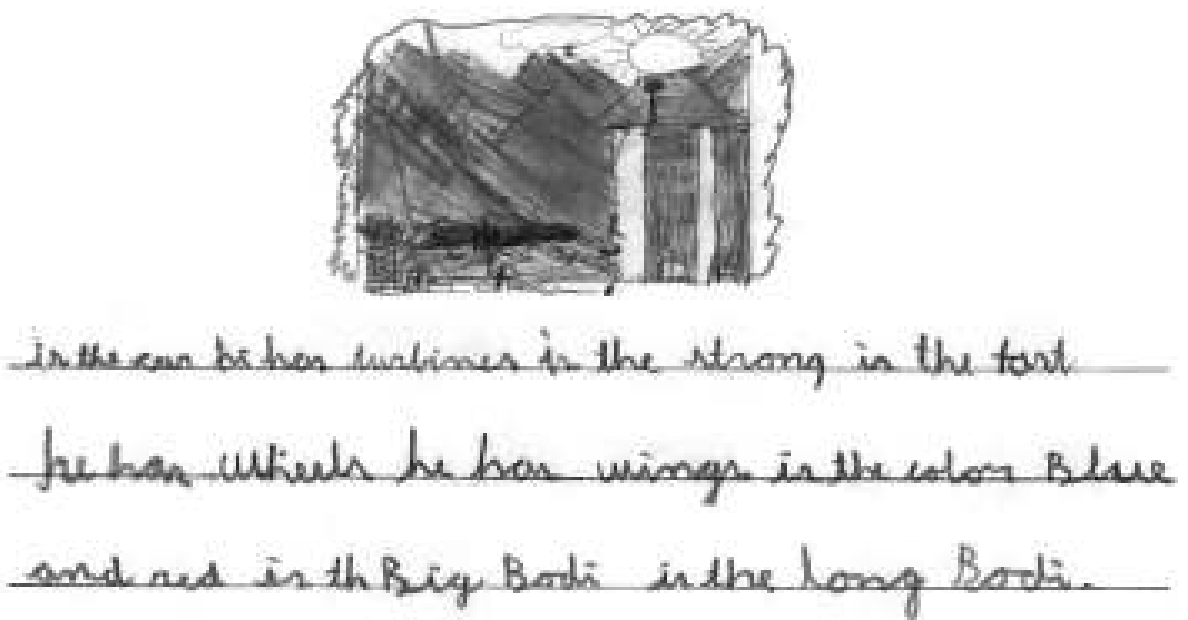

(Writing Sample No 11 W6P2CGG, October 13th 2006) 
Figure 4. Spanish as a resource
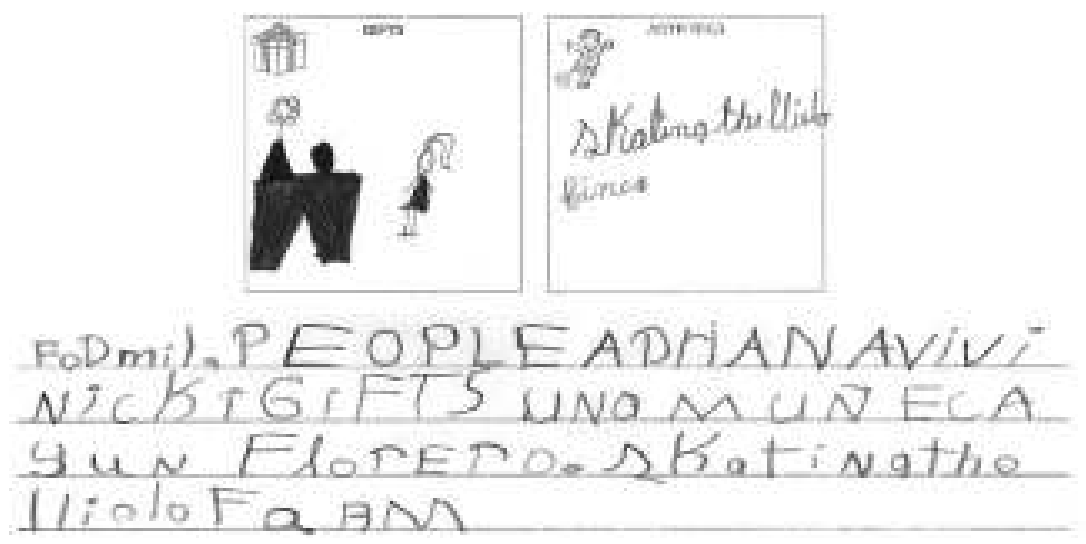

(Writing Sample No 12 W8P2LCA, October 27th 2006)

\section{Conclusions}

The children' cognitive skills development was an ongoing process evident by three stages which were frequently mediated by the collaboration of both the teacher and the peers. The following chart shows the cognitive functions that the children accomplished $(\sqrt{ })$ or did not accomplish $(X)$ during the process.

\begin{tabular}{|c|c|c|}
\hline \multicolumn{3}{|c|}{ First Stage: Uncertainty and Emerging Strategies (workshops 1-3) } \\
\hline & Cognitive Function & Explanation \\
\hline \multicolumn{3}{|r|}{ Input Phase } \\
\hline $\mathrm{x}$ & a. Clear perception and linguistic abilities & $\begin{array}{l}\text { Most of the children were unable to understand instructions, } \\
\text { and some images created confusion }\end{array}$ \\
\hline$x$ & b. Systematic exploration & The children were not systematic but impulsive \\
\hline \multicolumn{3}{|c|}{ Elaboration Phase } \\
\hline$\sqrt{ }$ & c. Selection of relevant information & Some students used prior knowledge \\
\hline$\sqrt{ }$ & d. Amplitude and flexibility & $\begin{array}{l}\text { Some children used different sources of information (books, } \\
\text { words from the board and the environmental print) }\end{array}$ \\
\hline$\sqrt{ }$ & e. Comparative behavior & $\begin{array}{l}\text { Some children had the capability to make comparisons and } \\
\text { relate objects }\end{array}$ \\
\hline$\sqrt{ }$ & f. Cognitive classification & Some children had the ability to organize data into categories \\
\hline$\sqrt{ }$ & g. Answers control & Few children reflected on how to do the task \\
\hline
\end{tabular}




\begin{tabular}{|c|c|c|}
\hline \multicolumn{3}{|c|}{ Second Stage: The Difficulties remain but the Strategies increase (workshops 4-6) } \\
\hline \multicolumn{3}{|r|}{ Input Phase } \\
\hline $\mathrm{X}$ & $\begin{array}{l}\text { a. Clear perception and linguistic abili- } \\
\text { ties }\end{array}$ & $\begin{array}{l}\text { Some children found it difficult to understand instructions } \\
\text { and some images created confusion. }\end{array}$ \\
\hline $\mathrm{X}$ & b. Systematic exploration & Some children were not systematic, but impulsive \\
\hline \multicolumn{3}{|c|}{ Elaboration Phase } \\
\hline $\mathrm{X}$ & c. Selection of relevant information & $\begin{array}{l}\text { The children were unable to select relevant information to } \\
\text { synthesize the pictures }\end{array}$ \\
\hline$\sqrt{ }$ & d. Behavior planning & Some students became more systematic \\
\hline$\sqrt{ }$ & $\begin{array}{l}\text { e. Perception and definition of a prob- } \\
\text { lem }\end{array}$ & Some children identified what the task was about \\
\hline \multicolumn{3}{|r|}{ Output Phase } \\
\hline$X$ & f. Visual transport & $\begin{array}{l}\text { The children found it difficult to visually transport the images } \\
\text { from the jigsaw puzzle }\end{array}$ \\
\hline \multicolumn{3}{|c|}{ Third Stage: Cognitive Strategies Strengthening (workshops 7-9) } \\
\hline \multicolumn{3}{|c|}{ Elaboration Phase } \\
\hline$\sqrt{ }$ & a. Behavior planning & Most children planned more strategically the necessary \\
\hline$\sqrt{ }$ & $\begin{array}{l}\text { b. Perception and definition of the } \\
\text { problem }\end{array}$ & $\begin{array}{l}\text { Most children identified and explained instructions in their } \\
\text { L1 }\end{array}$ \\
\hline$\sqrt{ }$ & c. Amplitude and flexibility & $\begin{array}{l}\text { More use of different sources (books, environmental print, } \\
\text { etc) }\end{array}$ \\
\hline$\sqrt{ }$ & d. Comparative behavior & Ability to continue looking for differences and similarities \\
\hline$\sqrt{ }$ & e. Cognitive classification & Ability to continue organizing items into categories \\
\hline \multicolumn{3}{|r|}{ Output Phase } \\
\hline$\sqrt{ }$ & f. Visual transport & Most children were able to transport these pictures visually \\
\hline$\sqrt{ }$ & g. Answer control & Most students reflected before doing a task \\
\hline
\end{tabular}

The strengthening of the cognitive prerequisites mentioned above proved that instructional materials positively influenced the children's cognitive skills development since the first graders were able to identify, compare, classify, differentiate, analyze pictures, decode and use divergent thinking during the implementation. However, the analysis showed that the children could not synthesize information possibly because they lacked linguistic resources and used part of the information given.

During the process, I observed that the students developed their cognitive skills through both, building their own strategies and frequently reflecting before providing an answer. The children showed that cognitive abilities are 
better developed when the person reflects upon what he or she does. This idea is supported by Ramesh (2009) who claims that "learners who are metacognitively aware know what to do when they encounter difficulties in learning; that is, they have strategies for figuring out what they need to do. The use of metacognitive strategies ignites one's thinking and can lead to more profound learning and improved performance, especially among learners who are struggling" (p.1).

Additionally, there was an essential extrinsic issue that facilitated language learning and cognition enhancement: teacher and peer mediation. Such interaction was characterized by the use of some functions of code-switching, which were evident not only in the teacher's discourse, but also in the students' interactions. Regarding the former, the teacher made use of the Repetitive Function to make sure the instructions were clear. Sert (2005) explains this function allows the teacher to clarify meaning when using the native language. In relation to the former, the children employed Reiteration while doing the tasks designed. By means of this function, the message in the target language is repeated by the student in his native language through which he tries to give meaning by repetition (Eldridge, as cited in Sert, 2005).

In regard to the second category, children developed as EFL writers by using their prior knowledge, incorporating L1 into the L2 system and creating a unique style to convey ideas in writing. Children's ideas for written tasks relied on three main sources: home (pets, toys and massmedia), school and friendship. However, massmedia was the most predominant influence in the children's literacy process. Cartoon characters and movies helped children invent and describe pictures, create stereotypes (wickedness) and hypothesize about unknown phenomena (UFO's).

Children went through a continuing process that moved from writing just words to long sentences and paragraphs. Students evolved into creative writers who used story phrases (once upon a time), interjections, connectors, time adverbs, linking words, punctuation marks, adjectives, interrogations, exclamations and narrative sentences in order to convey ideas, create intertextual dialogues among pictures and interact with the reader.

The analysis of the artifacts also showed that the first graders internalized and overused language features such as verbs, articles and pronouns by means of which they created their own L2 grammar. Hence, some of these elements were generalized and this generalization of known words showed that the children hypothesized about the L2 writing system and developed interim L2 structures that let them convey ideas and develop their language acquisition process when writing independently.

The children's native language (Spanish) played a key role in their language acquisition process since it was a linguistic resource by which they invented L2 spelling, code-switched, used L1 syntax and translated sentences literally from Spanish into English. In this study, the use of L1 was not a negative interference but rather a back-up system that helped them make meaning, hypothesize about the L2 writing system and construct their knowledge about it.

\section{Pedagogical Implications}

Linguistic codes and mind processes need to be intertwined in the teaching-learning process because students should be given the chance to do meaningful and cognitively useful language tasks instead of just practicing isolated structures. Educators should motivate learners and encourage them to strengthen their cognitive functions to become both good speakers and good thinkers.

If it is true that mediation facilitates the development of cognitive skills and fosters social 
construction of knowledge (Martinez, 2001), it is also true that the use of students' native language is crucial to put into practice the SCM model since L1 is a means to encourage students to learn, assure problem identification and enhance thinking. Thus, the use of L1 in this study leads us to evaluate attitudes towards the use of Spanish in English classes because participants do not use L1 out of negligence, but rather for communicative purposes.

Writing in early stages should not be associated with correcting since "mistakes" reveal children's ability to hypothesize about language. More tolerance towards errors needs to be cultivated at the beginning of the process to make writing enjoyable for children and to give them the opportunity to notice that literacy is an essential part of their lives to read and interpret the world and communicate with others.

\section{References}

Arhar, J.M, Holly, M.L, \& Kasten, W.C. (2001). Elements of design: Planning and documenting the action. Action Research for Teachers, 11, 131-166.

Burns, A. (1999). Definitions and processes. Collaborative Action Research for English Language Teachers, $2,20-44$

Cooper, J. D. (1993a). Activating and developing prior knowledge. Literacy: Helping children construct meaning, 3, $107-121$.

Cooper, J. D. (1993b). Instruction in reading and writing. Literacy: Helping Children Construct Meaning, 2, $40-55$

Cooper, J. D. (1993c). Writing and the construction of meaning. Literacy: Helping Children Construct Meaning, 2, $431-434$.

Cunningsworth, A. (1984). Adaptation and innovation. Evaluating and Selecting EFL Teaching Materials, 9, 65-73.

Ellis, R. (1997). Second language acquisition research: An overview. Second Language Acquisition Research and Language Teaching, 1, 11-39.

Ferreiro, E. (1994). Problems and pseudo-problems in literacy development: Focus on Latin America. In
Verhoeven. L, Functional Literacy (223-235). Philadelphia: John Benjamins Publishing Company.

Freeman, D. (1998). Collecting and analyzing data. Doing teacher - research: From Inquiry to Understanding, 5, 86-119.

Hubbard, R., \& Power, B. (1999). A guide for teacher - researchers. Living the Questions, 4, 82-116.

lafrancesco, G. (2002). Desarrollo y evaluación de las funciones cognitivas a través del aprendizaje mediado. Revista Cultura, 204, 23-34.

lafrancesco, G. (2005). Desarrollo cognitivo: La Modificabilidad Estructural Cognitiva MEC y el Programa de Enriquecimiento Instrumental PEl. Educación y Pedagogía Gimandina, 2, 4-9.

Kern, R. (2000). Writing as design. Literacy and Language Teaching, 6, 171-190.

Martinez, J. (2001). ARPA: Actividades para el Refuerzo del Potencial de Aprendizaje. Propuesta Didáctica Arpa 1 y 2. Madrid, Grupo Editorial Bruno.

Martinez, J., Brunet, J., \& Farrés, R. (1991). Análisis y modificación del acto mental. Metodología de la Mediación en el P.E.I: Orientaciones y Recursos para el Mediador, 2, 29-44.

McDonough, J., \& Shaw, C. (2000). The framework of materials and Methods. Materials and Methods in ELT: A teacher's Guide, 1, 2-18.

Mejía de, A.M. (1998). Bilingual Storytelling: Code-switching, discourse control, and learning opportunities. TESL Journal. Vol 7 (6), Winter, p. 4-10.

Merriam, S. (1998). Case study research in education. A Qualitative Approach. Jossey-Bass Inc, Publishers. San Francisco.

Nuñez, A, Tellez, M.F, Castellanos, J, \& Ramos, B. (2009). A Practical materials development guide for EFL pre-service, novice, and in-service teachers. The Materials Development Scaffolding, 3, 28-49.

Pérez, B. (1998). Writing across writing systems. Sociocultural Contexts of Language and Literacy, 3, 49-63.

Piaget, J. (1983). El desarrollo del pensamiento. La Psicología de la Inteligencia, 5, 133-168.

Piaget, J. (1985). El desarrollo mental del niño. Seis Estudios de Psicología, 1, 11-107.

Pilonieta, G. (2003). Desarrollo del Potencial de Inteligencia y del Pensamiento Divergente: Un proceso de desarrollo pedagógico para los maestros del nuevo 
milenio. Modulo I-II. [Diskette]. Bogotá: Equipo Cisne, retrieved from the seminar on the Structural Cognitive Modifiability model in 2006.

Pilonieta, G. (2004). El potencial de aprendizaje: Una mirada desde la Modificabilidad Estructural Cognitiva de Reuven Feuerstein. Entrevista realizada por Germán Pilonieta. Revista Internacional Magisterio: Educación y Pedagogía, 12, 7-11.

Ramesh, R. (2009). Metacognitive Strategies for Enhancing second Language Acquisition. (Online), Retrieved Januay 18th, 2010, from http://wwwis- te-community.org/profiles/blogs/metacognitivestrategies-for

Richards, J. (2001). The role and design of instructional materials. Curriculum Development in Language Teaching, 8, 251-283.

Sert, O. (2005). The Functions of Code Switching in ELT Classrooms. (Online), Retrieved Januay 18th, 2010, from http://iteslj.org/Articles/Sert-CodeSwitching. html

Tomlinson, B. (1998). Introduction. Material Development in Language Teaching, 1-24.

\section{Appendix 1}

Workshop 1
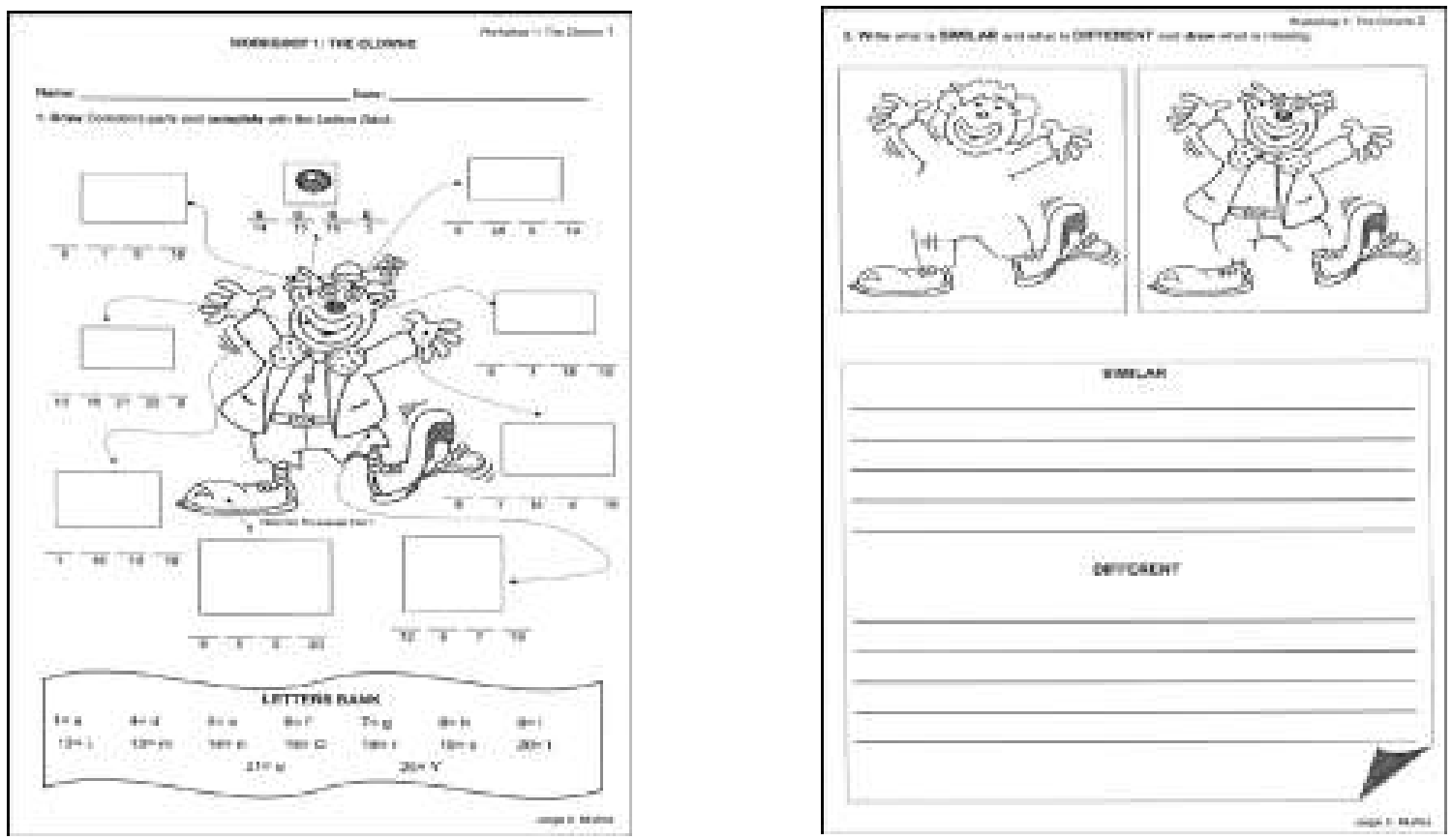
Instructional materials: a platform to enhance cognitive skills and writing development

Workshop 2
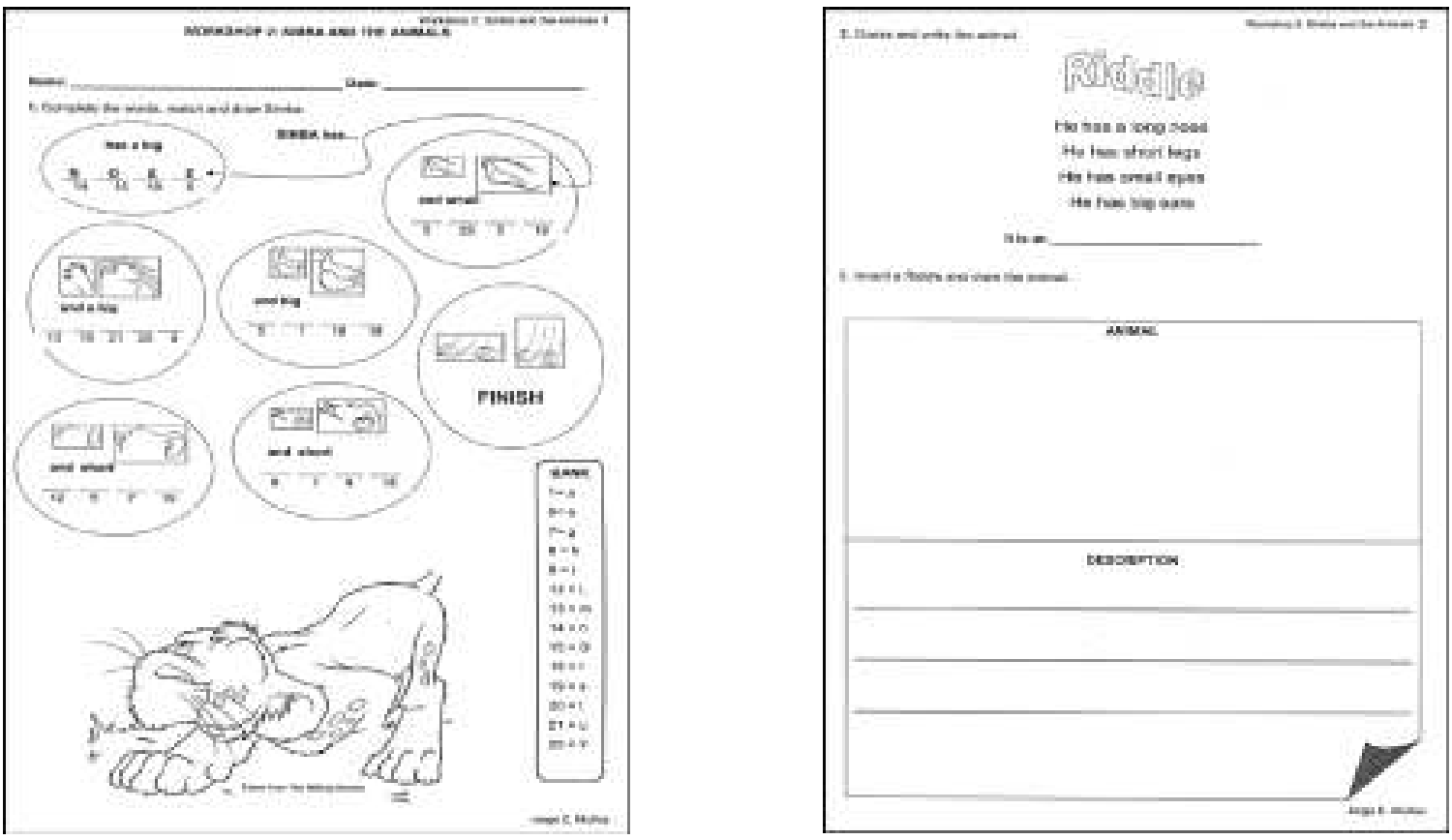

\section{Appendix 2}

\section{Workshop 3}
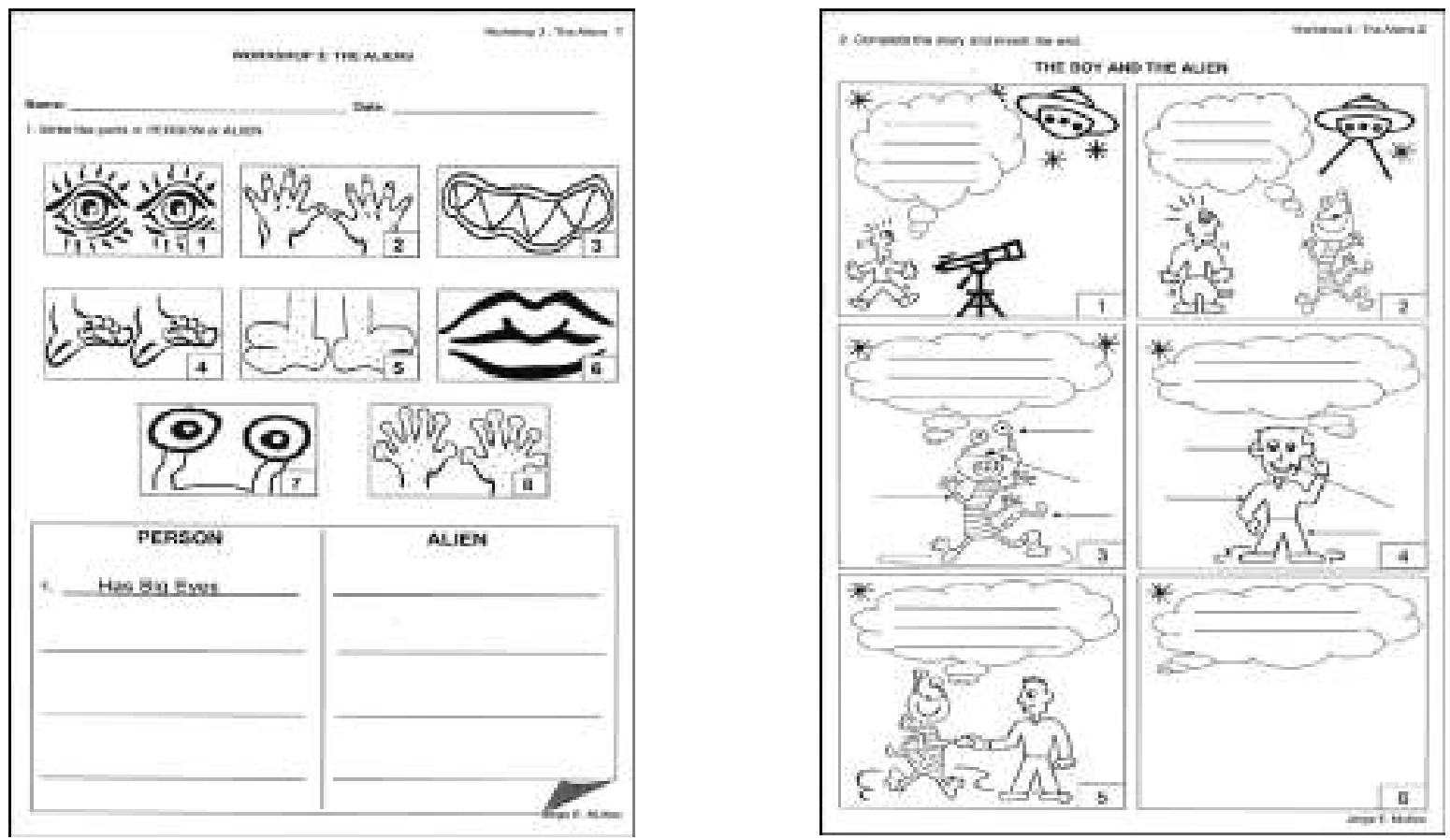
Jorge Enrique Muñoz Oyola

\section{Appendix 3}

\section{Workshop 4}
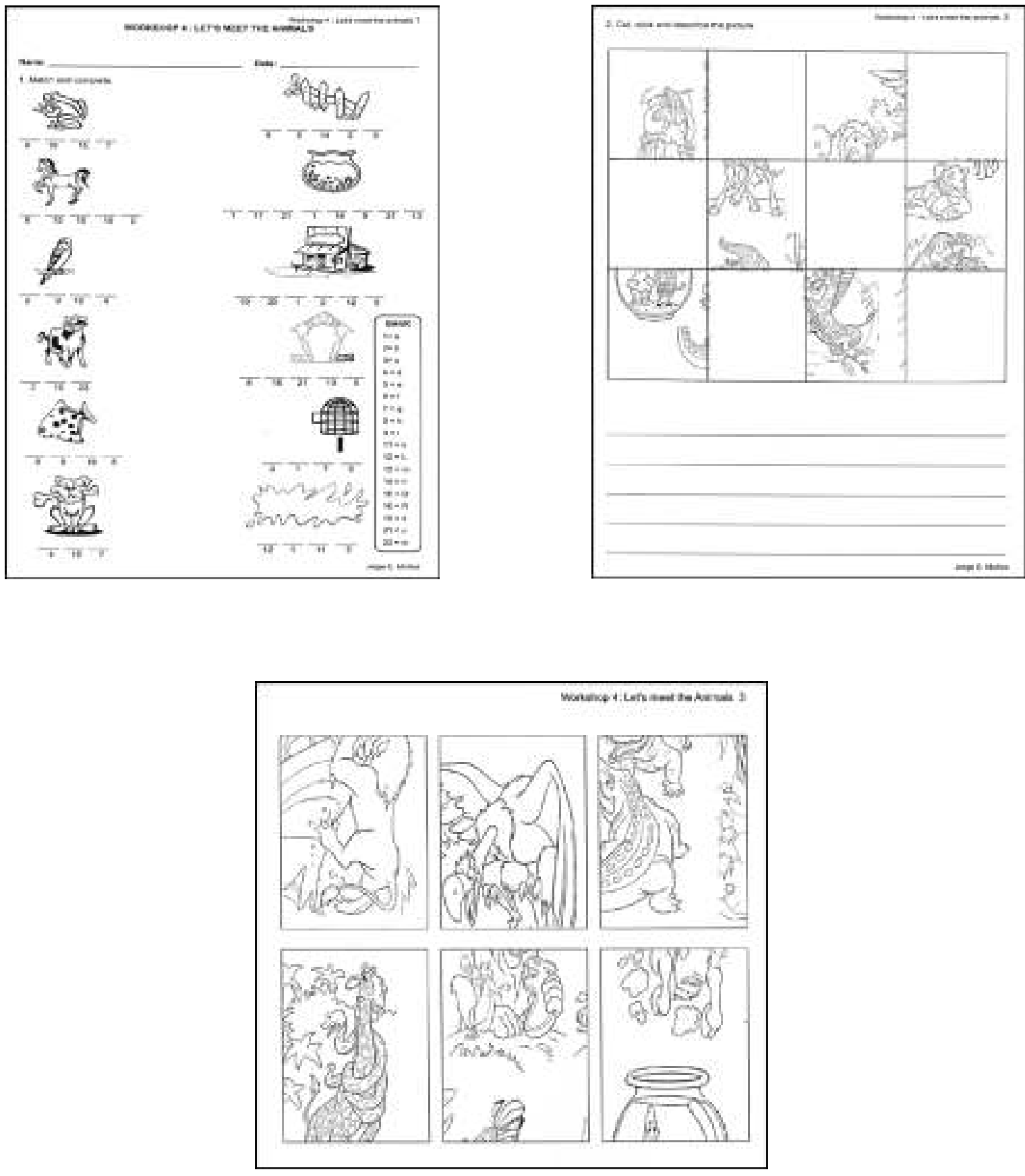
Workshop 5
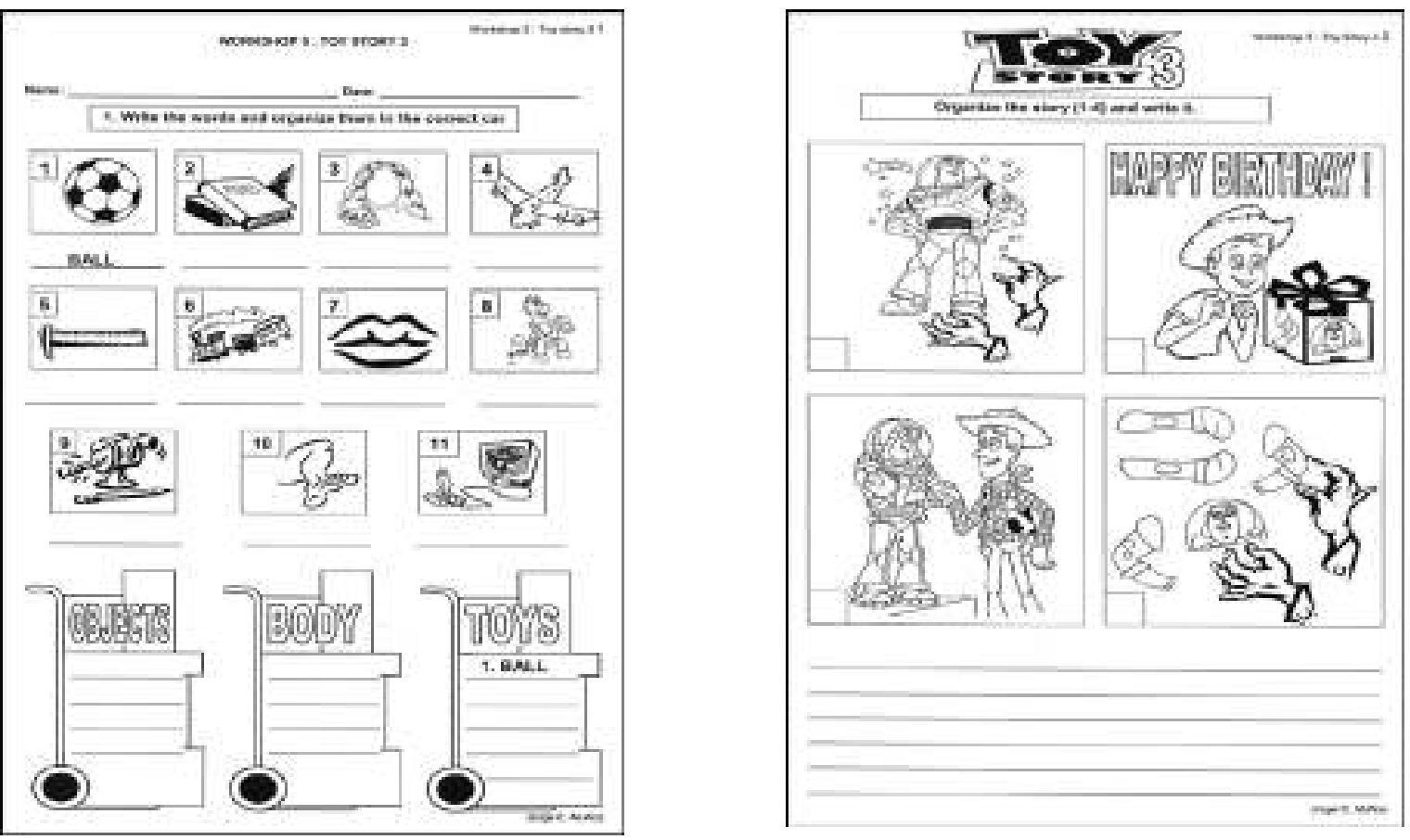

\section{Appendix 4}

Workshop 6
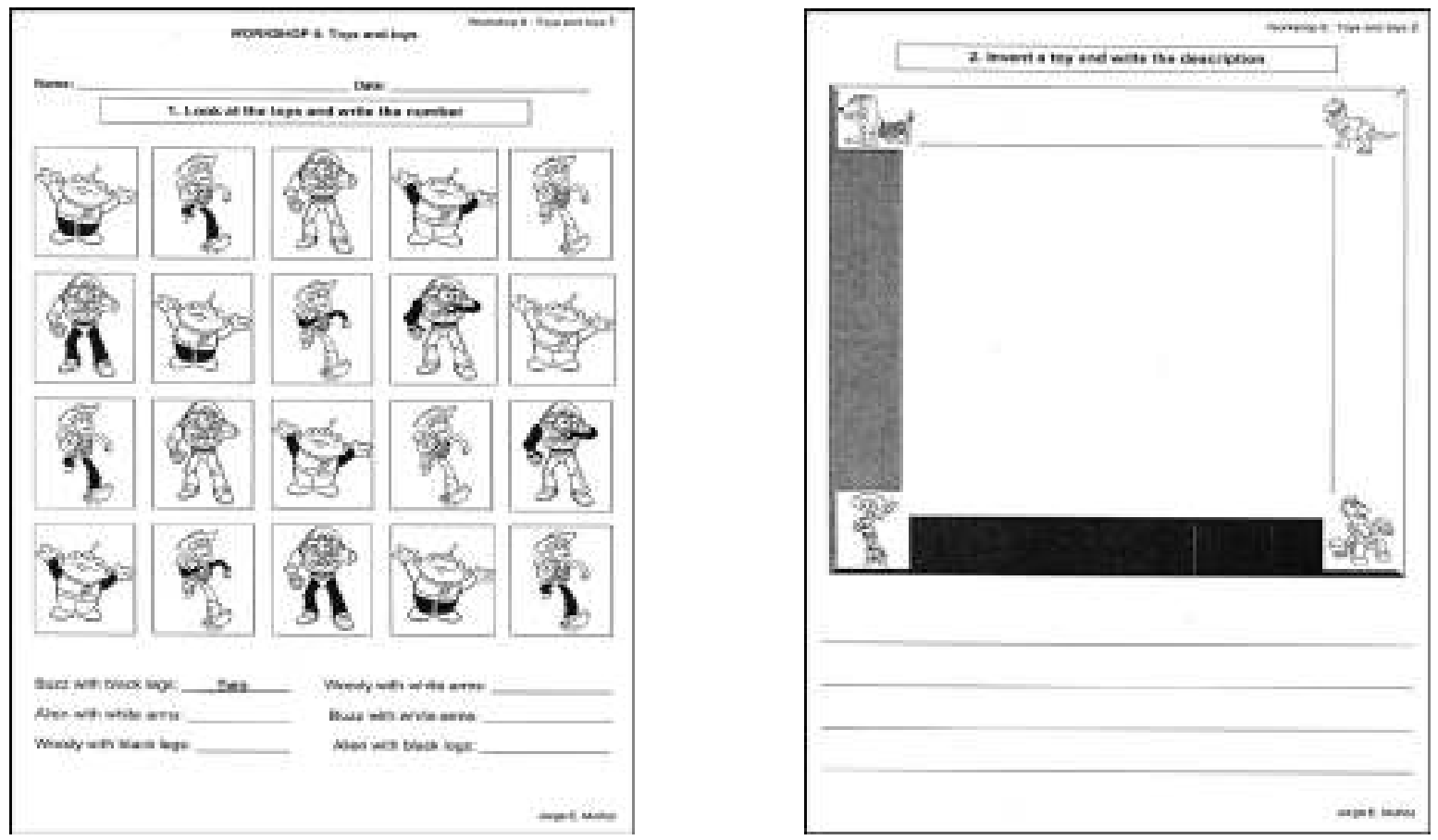
Jorge Enrique Muñoz Oyola

Workshop 7
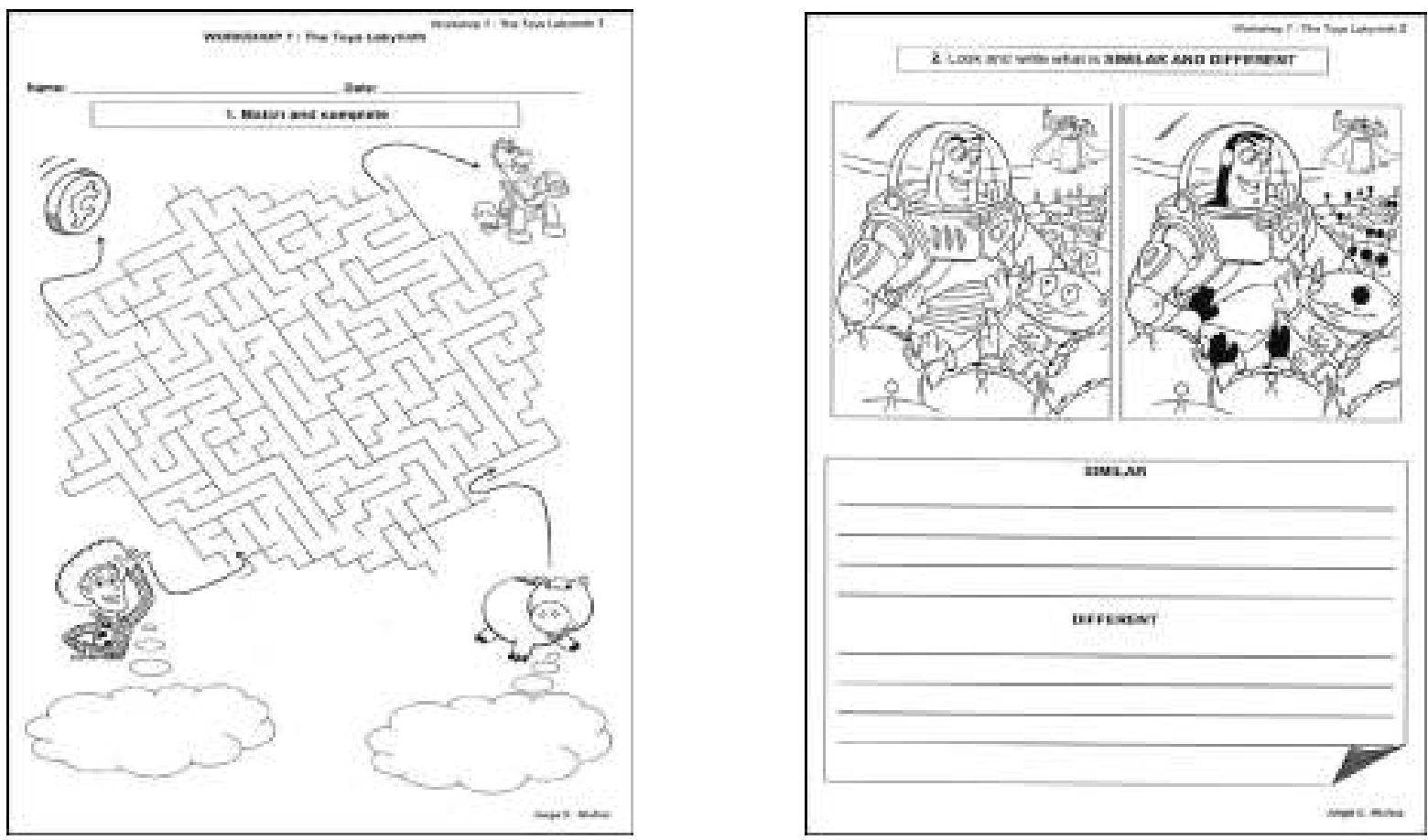

\section{Appendix 5}

Workshop 8
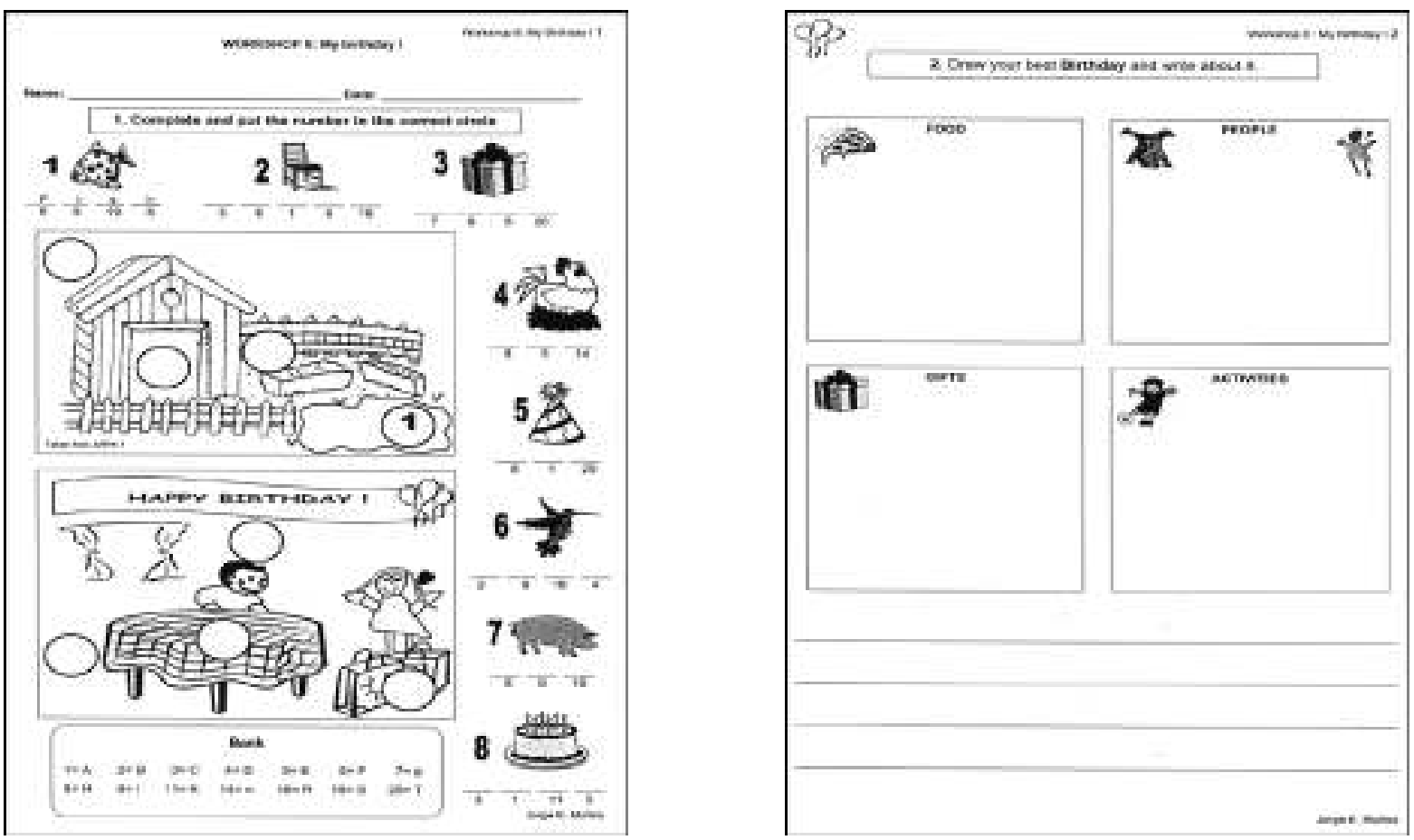
Workshop 9
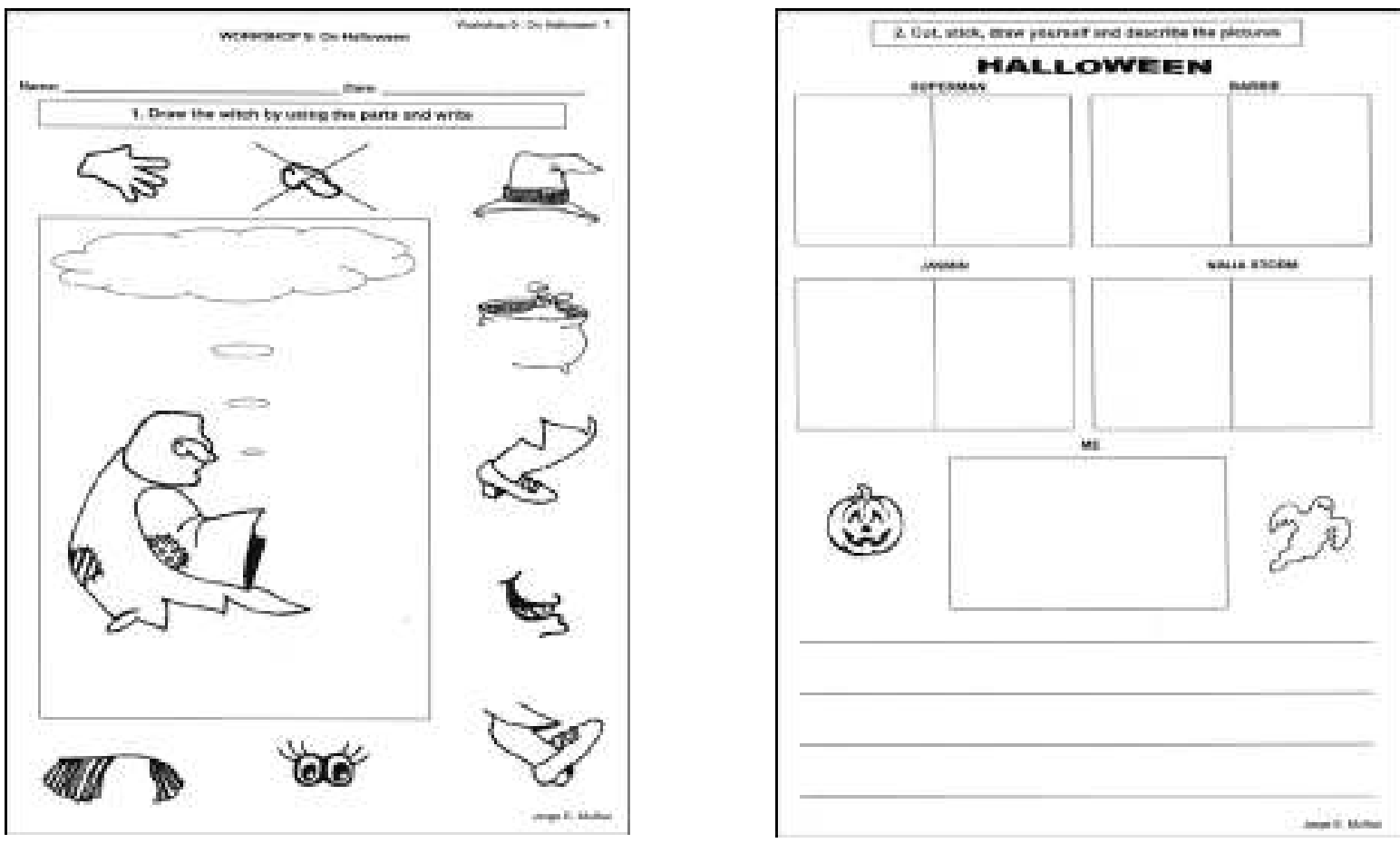

\section{Appendix 6}

Exploratory Stage Workshops

A. Fion conts


Jorge Enrique Muñoz Oyola

\section{Appendix 7}

Learning Log Sample

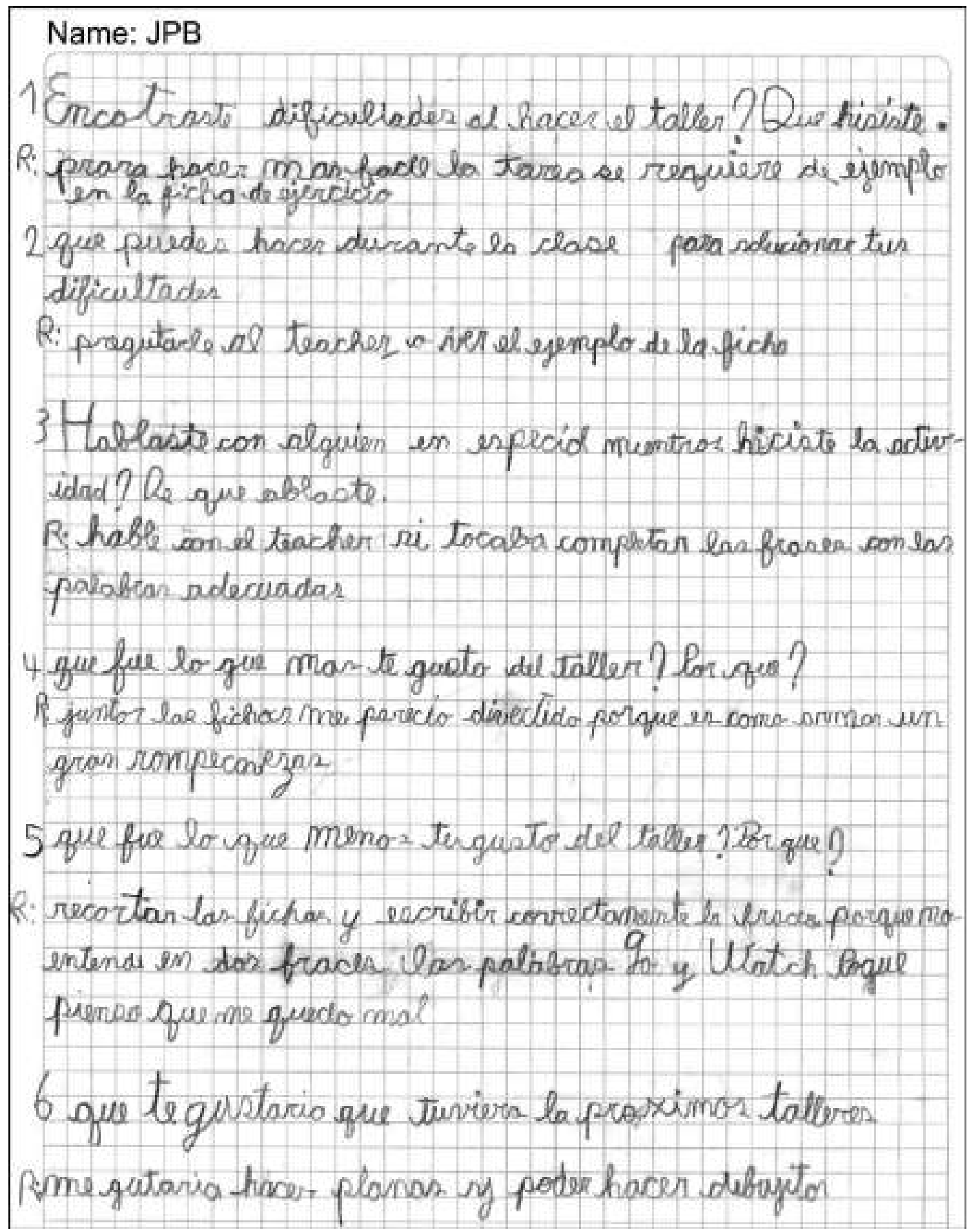


Instructional materials: a platform to enhance cognitive skills and writing development

\section{Appendix 8}

Needs Analysis Questionnaire

\begin{tabular}{|c|c|c|c|c|c|}
\hline \multicolumn{6}{|c|}{ Me gusta aprender ingiós viendo iolevieión en casa } \\
\hline & ORACIONES & No & Poco & $\begin{array}{l}\text { Mas o } \\
\text { Menos }\end{array}$ & \\
\hline 1 & Me gusta practictar soridoy y pronunciación & & & 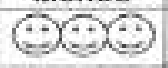 & \\
\hline 2 & Me gusta que el profesor me diga todos mis errores & & & & \\
\hline 3 & $\begin{array}{l}\text { En clase me gusta aprender pó medio de } \\
\text { Domversaciones. }\end{array}$ & & & & \\
\hline 4 & Me guste que el profesor me explique todo. & & & & \\
\hline 5 & Me guste aprender nuovas paiabras. & & & & \\
\hline 8 & $\begin{array}{l}\text { Me gusta aprender ai hablar con mis comparieros en } \\
\text { ingibs. }\end{array}$ & & & & \\
\hline 7 & Me gusta aprender nueves palabras al escucharles. & & & & \\
\hline B & Me guste aprender nueves palabras al veries. & & & & \\
\hline 9 & $\begin{array}{l}\text { Me gusta que ol protesor me progunte scbro temas } \\
\text { que me interesen? }\end{array}$ & (i) & & & \\
\hline 10 & $\begin{array}{l}\text { Me gusta aprender inglés trabajando en grupos } \\
\text { pequeños. }\end{array}$ & & & & \\
\hline 11 & $\begin{array}{l}\text { Me gusts que el profescr me de situaciones pare } \\
\text { resolver. }\end{array}$ & & & & \\
\hline 12 & $\begin{array}{l}\text { Me gusta sair del salán con mis companeros y } \\
\text { practicar ingibs. }\end{array}$ & & & & \\
\hline 13 & En clase de inglés me gusta aprender leyendo. & & & & \\
\hline 14 & Me gusta escribir todo en el cuaderno. & & $\Leftrightarrow \approx$ & $\Leftrightarrow$ & \\
\hline 15 & En clisse me dusta escuchar y usar CD's. & & & & \\
\hline 18 & $\begin{array}{l}\text { Me gusta que el profesar me ayude a encontrar los } \\
\text { arrores que cometo. }\end{array}$ & & $\Leftrightarrow)$ & $\Leftrightarrow x$ & \\
\hline 17 & $\begin{array}{l}\text { En clase me gusta aprender por medio de dibujos, } \\
\text { peliculas y videos. }\end{array}$ & & & & \\
\hline 10 & Me gusta eprender ing/4s con loda la clase. & & $\theta \otimes$ & $\Leftrightarrow x$ & \\
\hline 19 & Me guats aprender ing/es cuando trabajo en parejas. & & $\Leftrightarrow \otimes$ & $\Leftrightarrow(\cdots)$ & \\
\hline 20 & En clase, me gusta aprender por medio de juegos. & & $\theta \times$ & $\Leftrightarrow x+2$ & \\
\hline 21 & Mo gusta estudiar inglos solo, & & $\Leftrightarrow)$ & 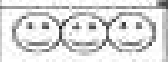 & \\
\hline 22 & $\begin{array}{l}\text { Me gusta aprender ingles cuando desarrolio las } \\
\text { actividades que los libros tienen. }\end{array}$ & & & $\Leftrightarrow \%$ & \\
\hline 23 & $\begin{array}{l}\text { Me gusta aprender inglés cuando desarrolio los } \\
\text { talleres que ef profesor llova a la clese. }\end{array}$ & (i) & $\Leftrightarrow \otimes$ & $\Leftrightarrow \times)$ & $\because x \Leftrightarrow(\cdots)$ \\
\hline
\end{tabular}

